МОГУЋНОСТИ ИЗБОРА МЕТОДОЛОГИЈЕ У ПРОЦЕНИ РИЗИКА НА РАДНОМ МЕСТУ И У РАДНОЈ ОКОЛИНИ

Љиљана Кулић ${ }^{1}$, Миливоје Гаљак², Страхиња Кулић ${ }^{3}$

\title{
POSSIBILITY OF CHOICE OF METHODOLOGY FOR RISK ASSESSMENT IN THE WORKPLACE AND THE WORKING ENVIRONMENT
}

Ljiljana Kulić, Milivoje Galjak, Strahinja Kulić

\section{Сажетак}

Увод: Према Закону о безбедности и здрављу на раду (Службени гласник РС 101/05) и Правилнику о начину и поступку прочене ризика на радном месту и у радној околини (Службени гласник РС 72/06), доношење Акта о прочени ризика на радном месту и у радној околини је обавеза сваког послодавиа. На располагању је велики број метода за прочену ризика на раду и у радној околини.

Циљ рада је да укаже на могућности избора методологије области прочене ризика на радном месту и у радној околини.

Метод рада: Анализирани су подащуи и литература у области медицине рада, безбедности на раду, заштите на раду, методологије у процени ризика и актуелна правна регулатива у области процене ризика на радном месту и у радној околини.

Резултати рада и дискусија: У области безбедности и здравља на раду постоји обавеза израде акта о прочени ризика за свако предузеће и свако радно место. Методологија у проиени професионалног ризика, односно ризика на раду, различита је, јер су у пракси присутни различити приступи y прочени ризика. За процену ризика на радном месту користе се методе које могу бити: квалитативне, полуквантитативне и квантитативне. Квалитативне методе за процену ризика се базирају на личном искуству и расуђиваюу учесника у тиму за процену ризика и/или коришћењу расположивих квалитативних, ненумеричких

\section{Summary}

Introduction: According to the Law on Safety and Health at Work (Official Gazette of RS No. 101/05) and the Ordinance on the manner and procedure of risk assessment in the workplace and the working environment (Official Gazette of RS No. 72/06), the adoption of the Act on risk assessment in the workplace and the working environment is obligatory for each employer. There is a large number of methods for risk assessment at work and in the work environment.

The aim of the paper is to highlight the possibility of choice of methodology in the field of risk assessment in the workplace and the working environment.

Methods: We analyzed the data and literature in the field of occupational medicine, occupational safety, risk assessment methodology and the current legal regulations in the field of risk assessment in the workplace and the working environment.

Results and discussions: In the field of safety and health at work, there is an obligation of the decision on risk assessment for each company and each workplace. The methodology in assessing professional risk, i.e. risks at work is different, because different approaches to risk assessment are present in practice. To assess risks in the workplace, methods that may include qualitative, semi-quantitative and quantitative are being used. Qualitative methods for the assessment of risk are based on personal experience and judgment of the participants in the risk assessment team and/or use of avail-

\footnotetext{
${ }^{1}$ Доц. др Љиљана Кулић, Универзитет у Приштини, Медицински факултет, Косовска Митровица.

2 Др спец. Миливоје Гаљак, Дом здравља Звечан, на докторским студијама, Медицински факултет, Косовска Митровица.

${ }^{3}$ Мр Страхиња Кулић, дипл. есс., на докторским студијама, ПИО фонд, Београд.
} 
података. Типичне квалитативне методе за проиену ризика представљене су следећим матрицама за проиену ризика: Матрииа ризика $3 \times 3$; Матрища ризика $4 \times 5$ и Матрица ризика 5х5. Полуквантитативне или комбиноване методе за процену ризика имају у пракси широку примену, а прочена и рангирање ових величина заснива се на искуству и знању учесника у тиму за процену ризика. Постоје три врсте полуквантитативних метода: Матрична метода прочене ризика (AUVA; $B G) ;$ Табеларне методе проиене ризика (KINNEY; PILZ; GUARDMASTER; FINE; Метода Високе техничке школе струковних студија из Новог Сада и др.) и Графичка метода прочене ризика. Квантитативна метода прочене ризика полази од основног обрасиа за израчунавање ризика, где су све величине исказане нумерички: Ризик је производ вероватноће (V), фреквенције (F) и величине штете (H), а формула за израчунавање је: $R=V \times F \times H$.

Закључак: Методологија за прочену ризика је разноврсна и пружа могућност одабира једне методе или комбиначије метода, јер се методе могу комбиновати. Избор методе треба урадити на основу потреба и перформанси послодавиа, врсте делатности и других фактора. Честа појава је да се методе модификују, што омогућава развој и побољшање метода. Проиењивање ризика у односу на опасности и штетности треба да се изводи методом проиене, која је јасна, разумьива и једноставна за примену. У суштини без обзира на методу која се примени приликом проиене ризика мора се добити исти резултат.

Кључне речи: методологија, ризик, радно место.

able qualitative, non-numerical data. Typical qualitative methods for risk assessment are presented in the following matrix of risk assessment: Risk matrix 3x3; Risk matrix 4x5 and Risk matrix 5x5. Semiquantitative or combined methods for risk assessment are widely used in practice, and the evaluation and ranking of these values is based on experience and knowledge of participants in a risk assessment team. There are three types of semi-quantitative methods: Matrix method of risk assessment (AUVA; BG); Spreadsheets risk assessment methods (KINNEY, PILZ; GUARDMASTER; FINE; Method of High Technical School of Professional Studies in Novi Sad etc.) and Graphical method of risk assessment. Quantitative methods of risk assessment are based on the basic form for the calculation of risk, where all values are expressed numerically: Risk is the product of probability $(P)$, frequency $(F)$ and size of the damage $(H)$, and calculation formula is: $R=P x F x H$.

Conclusions: The methodology for the assessment of risk is very versatile and offers the possibility of deciding for one method or combination of methods. The choice of the method should be done based on the needs and performance of the employer, type of activity and other factors. Modifications of methods are a common occurrence, which enables their development and improvement. Risk assessment in relation to the dangers and harms need to be performed by the method of assessment, that is clear, understandable and easy to use. In fact, regardless of the method applied during the risk assessment, the same result must be obtained.

Key words: methodology, risk, work position. 
УВОД

$\mathrm{Y}$

области безбедности и здравља на раду неопходно је вршити процену професионалног ризика. Процена професионалног ризика је поступак утврђивања критичних места, поступака, стања и процеса у којима може доћи до угрожавања безбедности и здравља радника на радном месту и у радној околини. Да би се извршила процена ризика, неопходно је евидентирање и праћење свих фактора опасности и штетности у процесу рада. Да би се квалитетно приступило процени ризика потребно је добро познавање организације рада, радног процеса, средстава за рад, материјала и сировина које се користе у процесу рада, средстава и опреме за личну заштиту и др. Процена професионалног ризика омогућава да се применом одговарајућих мера ризици елиминишу или смање на прихватљив ниво.

Према Закону о безбедности и здрављу на раду (Службени гласник РС 101/05) и Правилнику о начину и поступку процене ризика на радном месту и у радној околини (Службени гласник РС 72/06), доношење Акта о процени ризика на радном месту и у радној околини је обавеза сваког послодавца без обзира на делатност и број запослених. $(1,2)$ На располагању је велики број метода за процену ризика на раду и у радној околини.

\section{ЦИљ РАДА}

Циљ рада је да укаже на могућности избора методологије области процене ризика на радном месту и у радној околини.

\section{МЕТОД РАДА}

Анализирани су подаци и литература у области медицине рада, безбедности на раду, заштите на раду, методологије у процени ризика и актуелна правна регулатива у области процене ризика на радном месту и у радној околини.

\section{РЕЗУЛТАТИ РАДА И ДИСКУСИЈА}

У области безбедности и здравља на раду постоји обавеза израде акта о процени ризика за свако предузеће и свако радно место. Процена ризика је континуални процес и захтева сталну допуну и измену акта о процени ризика у складу са променама у технологији, систематизацији, законској регулативи, појави акцидента и слично.

У складу са законском регулативом процена ризика обухвата:

- опште податке о послодавцу;

- опис технолошког и радног процеса, опис средстава за рад и њихово груписање и опис средстава и опреме за личну заштиту на раду;

- снимање организације рада;

- препознавање и утврђивање опасности и штетности на радном месту и у радној околини;

- процењивање ризика у односу на опасности и штетности;

- утврђивање начина и мера за отклањање, смањење и спречавање ризика;

- закључак и

- измене и допуне акта о процени ризика. ${ }^{(2)}$

Методологија у процени професионалног ризика, односно ризика на раду, различита је, јер су у пракси присутни различити приступи у процени ризика. Свака од постојећих метода за процену ризика мора омогућити процену свих ризика којима су радници изложени, процену ризика за сваког радника, процену ризика технолошки препознатог радног места и процену ризика у свим радним околинама. У процени професионалног ризика као проблем се јавља непостојање прецизног дефинисања поступка и процедура, критеријума и показатеља за процену професионалног ризика. Као последица тога постоје разлике у начину дефинисања поступка и критеријума процене. То отежава контролу квалитета процене професионалног ризика. $^{(3)}$ Постојање система управљања 
квалитетом и система безбедности, ISO 9001 и OHSAS 18001 су веома значајни, јер обезбеђују стандардизоване процедуре за све активности у оквиру одговарајуће делатности. Процењивање ризика у односу на опасности и штетности треба да се изводи методом процене, која је јасна, разумљива и једноставна за примену. ${ }^{(4,5)}$

За процену ризика на радном месту користе се методе које могу бити: квалитативне, полуквантитативне и квантитативне.

Квалитативне методе за процену ризика се базирају на личном искуству и расуђивању учесника у тиму за процену ризика и/или коришћењу расположивих квалитативних, ненумеричких података. Типичне квалитативне методе за процену ризика представљене су следећим матрицама за процену ризика: Матрица ризика $3 \times 3$; Матрица ризика $4 \times 5$ и Матрица ризика $5 \times 5$.

Полуквантитативне или комбиноване методе за процену ризика имају у пракси широку примену, а процена и рангирање ових величина заснива се на искуству и знању учесника у тиму за процену ризика. Постоје три приступа процене ризика код полуквантитативних метода: Матрична метода процене ризика (AUVA; $\mathrm{BG})$; Табеларне методе процене ризика (KINNEY; PILZ; GUARDMASTER; FINE; Метода Високе техничке школе струковних студија из Новог Сада и др.) и Графичка метода процене ризика. ${ }^{(6,7)}$

Квантитативне методе процене ризика полазе од основног обрасца за израчунавање ризика, где су све величине исказане нумерички: Ризик је производ вероватноће (V), фреквенције (F) и величине штете $(\mathrm{H})$, а формула за израчунавање је: $\mathrm{R}=\mathrm{V}$ x F x H.

\section{ЗАКЈЬУЧАК}

Свака од постојећих метода за процену ризика мора омогућити процену свих ризика којима су радници изложени, процену ризика за сваког радника, процену ризика технолошки препознатог радног места и процену ризика у свим радним околинама. Методологија за процену ризика је разноврсна и пружа могућност одлучивања за једну методу или комбинацију метода, jep се методе могу комбиновати. Избор методе треба урадити на основу потреба и перформанси послодавца, врсте делатности и других фактора. Честа појава је да се методе модификују, што омогућава развој и побољшање метода. Процењивање ризика у односу на опасности и штетности треба да се изводи методом процене, која је јасна, разумљива и једноставна за примену. У суштини без обзира на методу која се примени приликом процене ризика мора се добити исти резултат.

\section{ЛИТЕРАТУРА}

1. Закон о безбедности и здрављу на раду. Сл. гласник РС 101/2005.

2. Правилник о начину и поступку процене ризика на радном месту и у радној околини. Службени гласник РС $72 / 06$.

3. Nikolic B, Gemovic B. Application of risk assessment method in workplace and working environment, Safety and health at work and environmental protection. Бања Лука, 2009; 49-57.

4. Старчевић J, Илић М, Пауновић-Пфаф

J. Приручник за процену ризика. Globe design, Београд, 2010; 9-11.

5. Савић С, Станковић М. Теорија система и ризика. Факултет заштите на раду у Нишу, Универзитет у Нишу, 2010.

6. Николић Б. Нова метода за процену ризика, Мониторинг и експертиза у 
безбедносном инжењерингу. MESE

Journal 2012; 2(1), 5-23.

7. Николић Б, Ружић-Димитријевић љ.

Како даље - корекција методе за процену ризика радног места и радне околине у безбедности и здрављу на раду и њена шира примена, Процена ризика. Копаоник, 2009; 24-35.

Контакт: Доц. др Љиљана Кулић, Универзитет у Приштини, Медицински факултет, Косовска Митровица. 